medRxiv preprint doi: https://doi.org/10.1101/2021.10.21.21264378; this version posted October 26, 2021. The copyright holder for this preprint (which was not certified by peer review) is the author/funder, who has granted medRxiv a license to display the preprint in perpetuity.

It is made available under a CC-BY-NC-ND 4.0 International license .

\title{
Analyzing human knockouts to validate GPR151 as a therapeutic target for reduction of body mass index
}

Allan Gurtan ${ }^{1,13}$, John Dominy ${ }_{1}^{1,13}$, Shareef Khalid ${ }^{2,3,4,13}$, Linh Vong ${ }^{1}$, Shari Caplan ${ }^{1}$, Treeve Currie ${ }^{1}$, Sean Richards $^{1}$, Lindsey Lamarche ${ }^{1}$, Daniel Denning ${ }^{1}$, Diana Shpektor ${ }^{1}$, Anastasia Gurinovich ${ }^{1,5}$, Asif Rasheed $^{2}$, Shahid Hameed ${ }^{6}$, Subhan Saeed ${ }^{2}$, Imran Saleem ${ }^{6}$, Anjum Jalal ${ }^{7}$, Shahid Abbas ${ }^{7}$, Raffat Sultana $^{8}$, Syed Zahed Rasheed ${ }^{8}$, Fazal-ur-Rehman Memon ${ }^{9}$, Nabi Shah ${ }^{10}$, Mohammad Ishaq ${ }^{8}$, Amit $^{2}$ Khera $^{11}$, John Danesh ${ }^{12}$, Sekar Kathiresan ${ }^{11}$, Philippe Frossard ${ }^{2}$, Danish Saleheen ${ }^{2,3,4,14}$

1. Novartis Institutes for BioMedical Research, Cambridge, MA

2. Center for Non-Communicable Diseases, Karachi, Sindh, Pakistan

3. Department of Medicine, Columbia University Irving Medical Center, New York, NY, USA

4. Department of Cardiology, Columbia University Irving Medical Center, New York, NY, USA

5. Tufts Medical Center, Boston, MA

6. Punjab Institute of Cardiology, Lahore, Pakistan

7. Faisalabad Institute of Cardiology, Faisalabad, Pakistan

8. Karachi Institute of Heart Diseases, Karachi, Pakistan

9. Red Crescent Institute of Cardiology, Hyderabad, Pakistan

10. Department of Pharmacy, COMSATS University Islamabad, Islamabad, Pakistan

11. Center for Genomic Medicine, Department of Medicine, Massachusetts General Hospital, Boston, USA

12. BHF Cardiovascular Epidemiology Unit, Department of Public Health and Primary Care, Cambridge University \& Health Data Research UK, Wellcome Sanger Institute, Cambridge, UK

13. These authors contributed equally

14. Corresponding author (ds3792@cumc.columbia.edu)

\section{Abstract}

Novel drug targets for sustained reduction in body mass index (BMI) are needed to curb the epidemic of obesity, which affects 650 million individuals worldwide and is a causal driver of cardiovascular and metabolic disease and mortality. Previous studies reported that the Arg95Ter nonsense variant of GPR151, an orphan G protein-coupled receptor, is associated with reduced BMI and reduced risk of Type 2 Diabetes (T2D). Here, we follow up on GPR151 with the Pakistan Genome Resource (PGR), which is one of the largest exome biobanks of human homozygous loss-of-function carriers (knockouts) in the world. Among PGR participants, we identify 3 GPR151 putative loss-of-function (plof) variants (Arg95Ter, Tyr99Ter, and Phe175LeufsTer7) with a cumulative allele frequency of $2.2 \%$ and present at homozygosity. We confirm these alleles in vitro as loss-of-function. We test if GPR151 plof is associated with BMI, T2D, or other metabolic traits. GPR151 deficiency in complete human knockouts is not associated with a clinically significant difference in BMI. Moreover, loss of GPR151 confers a nominally significant increase in risk of T2D (odds ratio $=1.2$, p value $=0.03$ ). Relative to wild-type mice, Gpr $151^{-1}$ animals exhibit no difference in body weight on normal chow, and higher body weight on a high-fat diet, consistent with the findings in humans. Together, our findings indicate that GPR151 antagonism is not a compelling therapeutic approach for obesity.

\section{Introduction}

Obesity, defined as a body mass index (BMI) of $>30 \mathrm{~kg} / \mathrm{m}^{2}$, is a major global health concern. In 2015, $7.1 \%$ of global deaths were attributable to high BMI (Collaborators et al. 2017). Predictions estimate that half of the world's population will be obese by 2030 (Tremmel et al. 2017). By 2030 in the United States alone, $25 \%$ of the population may be severely obese, as defined by BMl $>35 \mathrm{~kg} / \mathrm{m}^{2}$ (Ward et al. 2019). Being overweight or obese leads to a steep increase in all-cause mortality (Global et al. 2016), largely through increasing risk for Type 2 Diabetes (T2D) (Al-Salameh et al. 2019), nonalcoholic fatty liver disease (NAFLD) (Diehl and Day 2018), and cardiovascular disease (CVD) (Collaborators et al. 2017). Reduction in BMI may promote remission of multiple conditions (Wolfe et al. 2016). 
medRxiv preprint doi: https://doi.org/10.1101/2021.10.21.21264378; this version posted October 26, 2021. The copyright holder for this preprint (which was not certified by peer review) is the author/funder, who has granted medRxiv a license to display the preprint in perpetuity.

It is made available under a CC-BY-NC-ND 4.0 International license .

Given the mortality, morbidity and public cost associated with obesity, there is a strong interest in identifying drug targets for sustained reduction in BMI. To date, two particular therapies that promote body weight reduction also reduce hospitalization and mortality from associated co-morbidities. Glucagon-like peptide-1 (GLP-1) agonists are incretin mimetics that can reduce body weight by up to $12 \%$ (Wilding et al. 2021), improve glycemic status (Niman et al. 2021), and reduce cardiovascular events (Niman et al. 2021). SGLT2 inhibitors prevent glucose re-uptake in the kidneys, reduce body weight by 2 $\mathrm{kg}$, improve glycemic status, reduce cardiovascular events, and improve kidney function (Neal et al. 2017; McMurray et al. 2019; Wiviott et al. 2019; Cannon et al. 2020; Heerspink et al. 2020; Packer et al. 2020). Both GLP-1 agonists and SGLT2 inhibitors modify glucose metabolism, nonetheless, their effect on body weight is consistent with the expectation that reduction of BMI is therapeutically beneficial.

Human studies have identified numerous genetic loci associated with BMI (Locke et al. 2015). However, many of the genes linked to these loci are either technically challenging to drug or are poorly validated as causal. For example, the fat mass and obesity-associated (FTO) gene encodes an mRNA demethylase (Gerken et al. 2007; Jia et al. 2011) strongly associated with BMI (Frayling et al. 2007). However a direct role for FTO in regulating BMI is mechanistically unclear and has been called into question by studies suggesting linkage to variants in nearby genes IRX3 and IRX5 (Smemo et al. 2014; Claussnitzer et al. 2015). Loss-of-function (LoF) variants in the melanocortin 4 receptor (MC4R) are associated with obesity in humans (Krude et al. 1998; Vaisse et al. 1998; Yeo et al. 1998). Though a compelling target for body weight reduction, MC4R modulators are associated with adverse cardiovascular side effects (Yeo et al. 2021). Identification of additional BMI-associated genes may provide greater insight into the biology of body weight control and yield genes for which therapeutic modulation is tractable.

G protein coupled receptors (GPCRs) are attractive drug targets that have been associated with numerous phenotypes in human genetics studies and in mouse models (Erlandson et al. 2018). Loss-offunction in GPR151, a member of this class of receptor, has been associated with decreased BMI (Emdin et al. 2018; Tanigawa et al. 2019; Akbari et al. 2021). Additionally, at GPR151, carriage of rare (alternative allele frequency [aaf] < 1\%) putative loss-of-function (plof) variants and bioinformatically predicted damaging missense variants have also been associated with a decrease in BMI (Akbari et al. 2021).

To date, homozygous plof carriers (human knockouts) have not been reported in detail. To follow up on the published genetic association for GPR151, we use the Pakistan Genome Resource (PGR), which is the world's largest biobank of human homozygous plof carriers (knockouts) identified through wholeexome sequencing of $>80,000$ participants. Here, we (i) identify homozygous carriers of GPR151 plof variants, including those specific to South Asia, (ii) confirm in vitro that these variants are loss-of-function, (iii) test if GPR151 knockouts are associated with BMI, T2D, or other metabolic traits, and (iv) characterize GPR $151^{-/}$mice for body weight.

\section{Results and Discussion}

\section{Association of GPR151 plof variants with BMI and cardiometabolic events}

The PGR at the Center for Non-Communicable Diseases (CNCD) in Pakistan is a large biobank of highly consanguineous participants. A medical history and numerous clinical measurements including BMI, T2D status, and myocardial infarction (MI) status, are available for most participants. In the PGR, we identified 48 homozygous carriers of three independent plof variants in GPR151 with a cumulative allele frequency of 2.2\% (Table S1). Variants included Arg95Ter, as well as Tyr99Ter and Phe175LeufsTer7 that are both highly enriched in South Asia. By comparison, 21 homozygous plof carriers were identified among 281,852 exome-sequenced participants in the UK Biobank study and 13 homozygous plof carriers in nonsouth-Asian populations of gnomAD (Karczewski et al. 2020).

GPR151 is expressed from a single exon, and nonsense substitutions are more likely to escape nonsense mediated decay (NMD) in single-exon genes. To determine if truncated proteins are expressed 
medRxiv preprint doi: https://doi.org/10.1101/2021.10.21.21264378; this version posted October 26, 2021. The copyright holder for this preprint (which was not certified by peer review) is the author/funder, who has granted medRxiv a license to display the preprint in perpetuity.

It is made available under a CC-BY-NC-ND 4.0 International license .

from GPR151 variant transgenes, we transiently transfected HEK293 cells with cDNA expression constructs corresponding to each variant with an N-terminal HA-tag. From transfected cells, total cell lysates and isolated membrane extracts were generated and evaluated by western blot (Figure 1). Wild type (WT) GPR151 protein expressed at high levels and was detected in both the total lysate and in membrane extracts. In contrast, Arg95Ter and Tyr99Ter were not detectable in either extract. Although, the Phe175LeufsTer7 variant protein was detectable in the both the total cell and membrane lysates and migrated at a size consistent with the expected truncation, it expressed at significantly lower levels compare to the wild-type, likely reflecting impaired stability. Our in vitro observations indicate that the GPR151 nonsense variants in PGR are loss-of-function alleles.

To test for associations with BMI, we analyzed plof variants individually and in a gene burden test. For our gene-burden analyses (caf $=2.2 \%$ ), our study was adequately powered $(80 \%$ at an $\alpha=0.05$ ) to detect a mean difference of $0.36 \mathrm{~kg} / \mathrm{m}^{2}$ of BMI in knockouts compared to non-carriers. Similarly, for Tyr99Ter (aaf $=1.8 \%)$, our study was adequately powered $(80 \%$ at an $\alpha=0.05$ ) to detect a mean difference of 0.40 units of BMI in knockouts compared to non-carriers. Neither the individual variants nor the plof gene burden showed statistically significant associations with BMI as compared to previous studies (Table 1). For the previously reported Arg95Ter and the South Asia-specific Tyr99Ter, knockouts were not found to have a significantly lower BMI compared to non-carriers. In human knockouts across all variants, we did not identify any clinically meaningful $(>5 \%)$ reduction in BMI $\left(26.7 \pm 4.4 \mathrm{~kg} / \mathrm{m}^{2}\right.$ in knockouts versus $26.3 \pm 3.3 \mathrm{~kg} / \mathrm{m}^{2}$ in non-carriers). We tested for associations with other relevant traits including waist hip ratio, cholesterol and triglyceride levels: No significant associations or consistent trends were observed (Table S2).

Next, we analyzed the GPR151 variants to assess reduction in T2D risk (Table 2). For gene-burden analyses, our study was powered to observe an odds ratio of T2D of 0.82 or lower ( $80 \%$ at an $\alpha=0.05$ ). Each plof variant was associated with a slight and non-significant increase in the risk for T2D. For the plof gene burden we observed a nominally significant increase in T2D $(P=0.03, O R=1.18$ [1.02 - 1.37]). Similar analyses for MI risk did not yield any significant associations (Table S3).

In total, complete loss of GPR151 function in human knockouts was not associated with clinically meaningful changes in BMI or other traits related to obesity or metabolism, and was associated with a modest increase in T2D risk.

\section{Body weight in Gpr151/ mice}

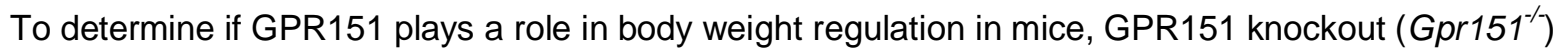
mice were generated using the CRISPR-Cas9 system. Loss of Gpr151 expression was evaluated by in situ hybridization (ISH). In wild-type, Gpr151/++ mice, Gpr151 mRNA expression was primarily observed in the habenular nucleus in the brain, consistent with prior reports (Broms et al. 2015) and in mucosal cells of the ilium and jejunum (Figure 2A and 2B). Gpr151 mRNA expression was not detected in Gpr151 - mice (Figure 2C and 2D).

Based on the published association between GPR151 plof and reduction in BMI, we predicted that the Gpr $151^{-\%}$ mice would have lower body weight when compared to their wild type controls. On a standard chow diet, no difference in body weights was observed between Gpr $151^{-/}$and wild type control mice of either sex (Figure 2E and 2G). Gpr $151^{-/}$male mice fed a high fat diet for 12 weeks weighed $\sim 16 \%$ more than their wild type controls (Figure 2E). Food intake was similar between the two groups suggesting an alternative mechanism for diet-induced weight gain in the Gpr $151^{-/-}$male mice (Figure 2F). Female Gpr $151^{-}$mice fed a high fat diet gained the same amount of weight as their wild type counterparts suggesting a potential sex difference in the response to an obesogenic diet (Figure 2G).

In summary, complete loss of function of GPR151 is not associated with clinically meaningful change (i.e., $>5 \%$ change) in BMI. We identified homozygous carriers of the previously published Arg95Ter plof and additional South Asia-specific plof variants in PGR, confirmed that plof variants are unstable in vitro, and 
medRxiv preprint doi: https://doi.org/10.1101/2021.10.21.21264378; this version posted October 26, 2021. The copyright holder for this preprint (which was not certified by peer review) is the author/funder, who has granted medRxiv a license to display the preprint in perpetuity. It is made available under a CC-BY-NC-ND 4.0 International license .

observed no statistically significant reduction in BMI in either heterozygous or homozygous carriers. Consistent with these observations, the body weights of male and female Gpr $151^{-1 /}$ mice were indistinguishable from wild type control mice on a standard chow diet, and were elevated in male Gpr151 ${ }^{1}$ mice on a high fat diet without a corresponding increase in food intake. The preclinical model data indicate that the lack of association with BMI is generalizable rather than a human population-specific phenomenon. Our results also highlight the importance of taking into account the effect estimates and directionality of multiple loss of function variants when prioritizing GWAS results for functional follow-up. In aggregate, loss of GPR151 does not affect BMI in human knockouts in a clinically meaningful way and GPR151 antagonism is likely not a compelling therapeutic strategy for BMI reduction or T2D remission in humans.

\section{Materials and Methods}

The Institutional Review Board (IRB) at the Center for Non-Communicable Diseases (IRB: 00007048, IORG0005843, FWAS00014490) approved the study. All participants gave informed consent.

\section{Variant QC and annotation}

This study included a subset of 30,833 individuals with Whole Exome Sequencing and 9,292 individuals with Whole Genome Sequencing from the Pakistan Genome Resource. Samples with low allele balance for a variant $(<0.2)$ or low depth $(<10)$ were set to missing and variants that had a missingness rate $>5 \%$ were removed. We also removed variants failing VQSR filters or failing visual validation on IGV. Variants were annotated using Variant Effect Predictor (McLaren et al. 2016) based on the Ensembl101 gene model. We obtained a list of high-quality protein coding transcripts with annotated start and stop codons. Variants annotated as frameshift, stop gained, splice acceptor and splice donor variants are considered plof variants. Additionally, we filtered out plofs annotated as 'low confidence' according to the filtering criteria in LOFTEE (Karczewski et al. 2020). Cumulative Allele Frequency was calculated as described (Minikel et al. 2020).

\section{Case classification}

Patients were categorized as T2D cases if they satisfied any one of the following criteria: 1) Documented history of diabetes, 2) $\mathrm{HbA} 1 \mathrm{c}>6.5 \%$, 3) use of glucose lowering medication or 4) fasting glucose $>126$ $\mathrm{mg} / \mathrm{dl}$. Patients were categorized as having had an Ml as described previously (Saleheen et al. 2009).

\section{Statistical analysis}

Associations with BMI $\left(\mathrm{kg} / \mathrm{m}^{2}\right)$, Cholesterol $(\mathrm{mg} / \mathrm{dl})$, triglycerides $(\mathrm{mg} / \mathrm{dl})$ and waist hip ratio were analyzed using multivariate linear regression adjusting for age, sex, $\mathrm{age}^{2}$ and top 5 genetic principal components (PCs). Associations with T2D and MI were analyzed using logistic regression, with Firth correction as implemented in glow (Mbatchou et al. 2021). Effect estimates from exomes and genomes data were meta analyzed using standard error weighted analysis as implemented in METAL (Willer et al. 2010). Power calculations were performed using Quanto v1.2 (Gauderman 2002).

\section{In vitro expression and western blot}

Human codon optimized cDNAs corresponding to GPR151 wild-type (NCBI reference sequence NP_919227.2) and corresponding nonsense mutant constructs were cloned in pcDNA3.1(+) mammalian expression vectors with hemagglutinin (HA) epitope tags (YPYDVPDYA) appended to the amino termini. Transient transfection of adherent HEK293 cells was performed using Lipofectamine 2000 (Invitrogen) in a 6-well plate format according to manufacturer's instructions. Cells were harvested 48-72 hours posttransfection by scraping, washed with PBS, and pelleted by centrifugation at $300 \mathrm{xg}$ for $5 \mathrm{~min}$. Whole-cell lysates were prepared from half of each sample by SDS extraction. Cells were resuspended in PBS containing $2.5 \%(\mathrm{w} / \mathrm{v}) \mathrm{SDS}$, samples were incubated at $4^{\circ} \mathrm{C}$ for 10 minutes with end-over-end rotation, and insoluble material was removed by centrifugation at $16,000 \mathrm{xg}$ for 15 minutes. Membrane fractions 
medRxiv preprint doi: https://doi.org/10.1101/2021.10.21.21264378; this version posted October 26, 2021. The copyright holder for this preprint (which was not certified by peer review) is the author/funder, who has granted medRxiv a license to display the preprint in perpetuity.

It is made available under a CC-BY-NC-ND 4.0 International license .

were isolated from remaining cell sample using the Mem-PER Plus Membrane Protein Extraction Kit (Thermo Scientific) according to manufacturer's instructions. Whole-cell lysates and isolated membrane fractions were analyzed by SDS PAGE and Western Blot against the HA epitope to detect GPR151 expression. The following antibodies were used: anti-HA monoclonal antibody (Clone 2-2.2.14, Invitrogen 26183); anti-Na+/K+ ATPase alpha-1 antibody (clone C464.6, Sigma 05-369); and anti-mouse IgG HRPconjugated antibody (R\&D Systems HAF007).

\section{Generation and phenotyping of Gpr151/- mice}

Mice lacking the Gpr151 gene were generated using the CRISPR-Cas9 system. All animal protocols were reviewed and approved by the Novartis Institutional Animal Care and Use Committee. The entire coding sequence of Gpr151 is contained on a single exon (Ensembl gene ID\# ENSMUSG00000042816). Two single guide RNA (sgRNA) sequences targeting sites just upstream of the translation start codon in exon 1 (ATCAAGCTCCTCCCTGCAGA) and within the 3' untranslated region (3' UTR) (TCATCAATATTGCTAAGCAG) were synthesized as crRNAs for Alt-R CRISPR-Cas9 system (Integrated DNA Technologies, Coralville, IA). A ribonucleoprotein mixture of the two crRNAs complexed with tracrRNA (Integrated DNA Technologies) and Cas9 protein (PNA Bio Inc, Newbury Park, CA) was electroporated into fertilized C57BL/6J embryos. The embryos were then implanted into pseudopregnant recipients. DNA lysates were prepared from tail biopsies of F0 generation pups using KAPA Mouse Genotyping Kit according to the manufacturer's instructions (Kapa BioSystems, Cat\# KK7302). Mice were genotyped by PCR using the following primers: For1 (5'-ACTTACAGACACTGTGAACAGC-3') anneals to sequence upstream of Gpr151 exon 1, For2 (5'-TGGCTCCCAGAGTGGATAGC-3') anneals to sequence within exon 1, and Rev1 (5'-TGCCTTTCTACTTACCAGGTTC-3') anneals to sequence downstream of the Cas9 cut site within the 3' UTR. For2 and Rev1 amplify a product of 614 bp corresponding to the wildtype allele, and For 1 and Rev1 amplify a product of $\sim 233$ bp corresponding to the null allele. PCR conditions were as follows: denaturation at $95^{\circ} \mathrm{C}$ for $3 \mathrm{~min}, 35 \mathrm{cycles}$ of $15 \mathrm{sec}$ at $95^{\circ} \mathrm{C}, 15 \mathrm{sec}$ at $60^{\circ} \mathrm{C}$, and $30 \mathrm{sec}$ at $72^{\circ} \mathrm{C}$, then $5 \mathrm{~min}$ at $72^{\circ} \mathrm{C}$. F0 founders were bred to C57BL/6J mice for germline transmission of mutant alleles. The null allele of the F1 founder line selected was confirmed by Sanger sequencing (GeneWiz, South Plainfield, NJ) to have a deletion of 1343 bp between the expected Cas9 cleavage sites. Heterozygous mice were interbred to generate homozygous offspring for studies.

At six-weeks of age, Gpr $151^{-/}$mice and wild type littermates were individually housed for body weight and food consumption measurements and provided either a standard chow diet (Purina Picolab 5053) or high fat diet in which $60 \% \mathrm{kcal}$ is derived from fat (Research Diets D12492i) with ad libitum access to water. Female mice were grouped housed for body weight studies. Food intake and body weight were measured 1-2 times per week for 12 weeks following exposure to high fat diet. Animals were maintained on a 12hour light/dark cycle. The study size is shown in Figure 2. One cohort was run for the study.

After 12 weeks of study, the mice were euthanized and brains collected to confirm GPR151 genotype by in situ hybridization. Samples from three animals of each genotype were used. Whole brains were fixed for 48 hours in $10 \%$ neutral buffered formalin and later embedded in paraffin. Four microns sections of each brain were collected. Staining was performed on the Leica Bond RX automated staining platform using the RNAscope 2.5 LSx Reagent Kit (ACDBio, Bio-Techne - 322440) for the following mouse Gpr151 probe (ACDBio, Bio-Techne - 317328) following the standard RNAscope Assay (Wang et al. 2012).

\section{Competing Interests Statement}

A.Gu., J.D., L.V., S.C., T.C., S.R., L.L, and D.D. are employees of the Novartis Institutes for BioMedical Research. D.Sh. is an employee of Bristol Myers Squibb. D.Sa. has received funding from Novartis, Regeneron Pharmaceuticals, GSK, Genentech, Astra Zeneca, Novo Nordisk, NGM, Eli Lilly and Variant Bio. S.Ka. is an employee of Verve Therapeutics, holds equity in Verve Therapeutics and Maze Therapeutics, and has served as a consultant for Acceleron, Eli Lilly, Novartis, Merck, Novo Nordisk, Novo Ventures, Ionis, Alnylam, Aegerion, Haug Partners, Noble Insights, Leerink Partners, Bayer 
medRxiv preprint doi: https://doi.org/10.1101/2021.10.21.21264378; this version posted October 26, 2021. The copyright holder for this preprint (which was not certified by peer review) is the author/funder, who has granted medRxiv a license to display the preprint in perpetuity.

It is made available under a CC-BY-NC-ND 4.0 International license .

Healthcare, Illumina, Color Genomics, MedGenome, Quest and Medscape. A.K. has served as a scientific advisor to Sanofi, Amgen, Maze Therapeutics, Navitor Pharmaceuticals, Sarepta Therapeutics, Verve Therapeutics, Veritas International, Color Health, Third Rock Ventures, and Columbia University $(\mathrm{NIH})$; received speaking fees from Illumina, MedGenome, Amgen, and the Novartis Institute for Biomedical Research; and received a sponsored research agreement from the Novartis Institute for Biomedical Research.

\section{Acknowledgements}

We thank Jovita Marcinkeviciene, Ryan Streeper, Tim Kelly, and Igor Splawski for helpful discussions.

\section{References}

Akbari P, Gilani A, Sosina O, Kosmicki JA, Khrimian L, Fang YY, Persaud T, Garcia V, Sun D, Li A et al. 2021. Sequencing of 640,000 exomes identifies GPR75 variants associated with protection from obesity. Science 373.

Al-Salameh A, Chanson P, Bucher S, Ringa V, Becquemont L. 2019. Cardiovascular Disease in Type 2 Diabetes: A Review of Sex-Related Differences in Predisposition and Prevention. Mayo Clin Proc 94: 287-308.

Broms J, Antolin-Fontes B, Tingstrom A, Ibanez-Tallon I. 2015. Conserved expression of the GPR151 receptor in habenular axonal projections of vertebrates. J Comp Neurol 523: 359-380.

Cannon CP, Perkovic V, Agarwal R, Baldassarre J, Bakris G, Charytan DM, de Zeeuw D, Edwards R, Greene T, Heerspink HJL et al. 2020. Evaluating the Effects of Canagliflozin on Cardiovascular and Renal Events in Patients With Type 2 Diabetes Mellitus and Chronic Kidney Disease According to Baseline HbA1c, Including Those With HbA1c <7\%: Results From the CREDENCE Trial. Circulation 141: 407-410.

Claussnitzer M, Dankel SN, Kim KH, Quon G, Meuleman W, Haugen C, Glunk V, Sousa IS, Beaudry JL, Puviindran V et al. 2015. FTO Obesity Variant Circuitry and Adipocyte Browning in Humans. N Engl J Med 373: 895-907.

Collaborators GBDO Afshin A Forouzanfar MH Reitsma MB Sur P Estep K Lee A Marczak L Mokdad AH Moradi-Lakeh M et al. 2017. Health Effects of Overweight and Obesity in 195 Countries over 25 Years. N Engl J Med 377: 13-27.

Diehl AM, Day C. 2018. Nonalcoholic Steatohepatitis. N Engl J Med 378: 781.

Emdin CA, Khera AV, Chaffin M, Klarin D, Natarajan P, Aragam K, Haas M, Bick A, Zekavat SM, Nomura A et al. 2018. Analysis of predicted loss-of-function variants in UK Biobank identifies variants protective for disease. Nat Commun 9: 1613.

Erlandson SC, McMahon C, Kruse AC. 2018. Structural Basis for G Protein-Coupled Receptor Signaling. Annu Rev Biophys 47: 1-18.

Frayling TM, Timpson NJ, Weedon MN, Zeggini E, Freathy RM, Lindgren CM, Perry JR, Elliott KS, Lango $\mathrm{H}$, Rayner NW et al. 2007. A common variant in the FTO gene is associated with body mass index and predisposes to childhood and adult obesity. Science 316: 889-894.

Gauderman WJ. 2002. Sample size requirements for association studies of gene-gene interaction. Am J Epidemiol 155: 478-484.

Gerken T, Girard CA, Tung YC, Webby CJ, Saudek V, Hewitson KS, Yeo GS, McDonough MA, Cunliffe S, McNeill LA et al. 2007. The obesity-associated FTO gene encodes a 2-oxoglutarate-dependent nucleic acid demethylase. Science 318: 1469-1472.

Global BMIMC, Di Angelantonio E, Bhupathiraju Sh N, Wormser D, Gao P, Kaptoge S, Berrington de Gonzalez A, Cairns BJ, Huxley R, Jackson Ch L et al. 2016. Body-mass index and all-cause mortality: individual-participant-data meta-analysis of 239 prospective studies in four continents. Lancet 388: 776-786.

Heerspink HJL, Stefansson BV, Correa-Rotter R, Chertow GM, Greene T, Hou FF, Mann JFE, McMurray JJV, Lindberg M, Rossing P et al. 2020. Dapagliflozin in Patients with Chronic Kidney Disease. N Engl J Med 383: 1436-1446.

Jia G, Fu Y, Zhao X, Dai Q, Zheng G, Yang Y, Yi C, Lindahl T, Pan T, Yang YG et al. 2011. N6methyladenosine in nuclear RNA is a major substrate of the obesity-associated FTO. Nat Chem Biol 7: 885-887. 
medRxiv preprint doi: https://doi.org/10.1101/2021.10.21.21264378; this version posted October 26, 2021. The copyright holder for this preprint (which was not certified by peer review) is the author/funder, who has granted medRxiv a license to display the preprint in perpetuity. It is made available under a CC-BY-NC-ND 4.0 International license .

Karczewski KJ, Francioli LC, Tiao G, Cummings BB, Alfoldi J, Wang Q, Collins RL, Laricchia KM, Ganna A, Birnbaum DP et al. 2020. The mutational constraint spectrum quantified from variation in 141,456 humans. Nature 581: 434-443.

Krude H, Biebermann H, Luck W, Horn R, Brabant G, Gruters A. 1998. Severe early-onset obesity, adrenal insufficiency and red hair pigmentation caused by POMC mutations in humans. Nat Genet 19: 155-157.

Locke AE Kahali B Berndt SI Justice AE Pers TH Day FR Powell C Vedantam S Buchkovich ML Yang J et al. 2015. Genetic studies of body mass index yield new insights for obesity biology. Nature 518: 197-206.

Mbatchou J, Barnard L, Backman J, Marcketta A, Kosmicki JA, Ziyatdinov A, Benner C, O'Dushlaine C, Barber M, Boutkov B et al. 2021. Computationally efficient whole-genome regression for quantitative and binary traits. Nat Genet 53: 1097-1103.

McLaren W, Gil L, Hunt SE, Riat HS, Ritchie GR, Thormann A, Flicek P, Cunningham F. 2016. The Ensembl Variant Effect Predictor. Genome Biol 17: 122.

McMurray JJV, Solomon SD, Inzucchi SE, Kober L, Kosiborod MN, Martinez FA, Ponikowski P, Sabatine MS, Anand IS, Belohlavek J et al. 2019. Dapagliflozin in Patients with Heart Failure and Reduced Ejection Fraction. N Engl J Med 381: 1995-2008.

Minikel EV, Karczewski KJ, Martin HC, Cummings BB, Whiffin N, Rhodes D, Alfoldi J, Trembath RC, van Heel DA, Daly MJ et al. 2020. Evaluating drug targets through human loss-of-function genetic variation. Nature 581: 459-464.

Neal B, Perkovic V, Matthews DR. 2017. Canagliflozin and Cardiovascular and Renal Events in Type 2 Diabetes. N Engl J Med 377: 2099.

Niman S, Hardy J, Goldfaden RF, Reid J, Sheikh-Ali M, Sutton D, Choksi R. 2021. A Review on the Efficacy and Safety of Oral Semaglutide. Drugs $R D$.

Packer M, Anker SD, Butler J, Filippatos G, Pocock SJ, Carson P, Januzzi J, Verma S, Tsutsui H, Brueckmann $\mathrm{M}$ et al. 2020. Cardiovascular and Renal Outcomes with Empagliflozin in Heart Failure. N Engl J Med 383: 1413-1424.

Saleheen D, Zaidi M, Rasheed A, Ahmad U, Hakeem A, Murtaza M, Kayani W, Faruqui A, Kundi A, Zaman KS et al. 2009. The Pakistan Risk of Myocardial Infarction Study: a resource for the study of genetic, lifestyle and other determinants of myocardial infarction in South Asia. Eur J Epidemiol 24: 329-338.

Smemo S, Tena JJ, Kim KH, Gamazon ER, Sakabe NJ, Gomez-Marin C, Aneas I, Credidio FL, Sobreira DR, Wasserman NF et al. 2014. Obesity-associated variants within FTO form long-range functional connections with IRX3. Nature 507: 371-375.

Tanigawa Y, Li J, Justesen JM, Horn H, Aguirre M, DeBoever C, Chang C, Narasimhan B, Lage K, Hastie T et al. 2019. Components of genetic associations across 2,138 phenotypes in the UK Biobank highlight adipocyte biology. Nat Commun 10: 4064.

Tremmel M, Gerdtham UG, Nilsson PM, Saha S. 2017. Economic Burden of Obesity: A Systematic Literature Review. Int J Environ Res Public Health 14.

Vaisse C, Clement K, Guy-Grand B, Froguel P. 1998. A frameshift mutation in human MC4R is associated with a dominant form of obesity. Nat Genet 20: 113-114.

Wang F, Flanagan J, Su N, Wang LC, Bui S, Nielson A, Wu X, Vo HT, Ma XJ, Luo Y. 2012. RNAscope: a novel in situ RNA analysis platform for formalin-fixed, paraffin-embedded tissues. J Mol Diagn 14: 22-29.

Ward ZJ, Bleich SN, Cradock AL, Barrett JL, Giles CM, Flax C, Long MW, Gortmaker SL. 2019. Projected U.S. State-Level Prevalence of Adult Obesity and Severe Obesity. N Engl J Med 381: 2440-2450.

Wilding JPH, Batterham RL, Calanna S, Davies M, Van Gaal LF, Lingvay I, McGowan BM, Rosenstock J, Tran MTD, Wadden TA et al. 2021. Once-Weekly Semaglutide in Adults with Overweight or Obesity. N Engl J Med 384: 989.

Willer CJ, Li Y, Abecasis GR. 2010. METAL: fast and efficient meta-analysis of genomewide association scans. Bioinformatics 26: 2190-2191.

Wiviott SD, Raz I, Sabatine MS. 2019. Dapagliflozin and Cardiovascular Outcomes in Type 2 Diabetes. Reply. N Engl J Med 380: 1881-1882.

Wolfe BM, Kvach E, Eckel RH. 2016. Treatment of Obesity: Weight Loss and Bariatric Surgery. Circ Res 118: $1844-1855$. 
medRxiv preprint doi: https://doi.org/10.1101/2021.10.21.21264378; this version posted October 26, 2021. The copyright holder for this preprint (which was not certified by peer review) is the author/funder, who has granted medRxiv a license to display the preprint in perpetuity. It is made available under a CC-BY-NC-ND 4.0 International license.

Yeo GS, Farooqi IS, Aminian S, Halsall DJ, Stanhope RG, O'Rahilly S. 1998. A frameshift mutation in MC4R associated with dominantly inherited human obesity. Nat Genet 20: 111-112.

Yeo GSH, Chao DHM, Siegert AM, Koerperich ZM, Ericson MD, Simonds SE, Larson CM, Luquet S, Clarke I, Sharma S et al. 2021. The melanocortin pathway and energy homeostasis: From discovery to obesity therapy. Mol Metab 48: 101206. 
medRxiv preprint doi: https://doi.org/10.1101/2021.10.21.21264378; this version posted October 26, 2021. The copyright holder for this preprint (which was not certified by peer review) is the author/funder, who has granted medRxiv a license to display the preprint in perpetuity.

Tables

Table 1. GPR151 associations with BMI

\begin{tabular}{|c|c|c|c|c|c|c|c|c|}
\hline $\begin{array}{l}\text { GRCh38 } \\
\text { chr:pos }\end{array}$ & $\begin{array}{l}\text { Reference } \\
\text { allele }\end{array}$ & $\begin{array}{l}\text { Alternate } \\
\text { allele }\end{array}$ & HGVSp & $\begin{array}{l}\text { Heterozygous } \\
\text { carriers }\end{array}$ & $\begin{array}{c}\text { Homozygous } \\
\text { carriers }\end{array}$ & $\mathbf{P}$ & $\begin{array}{c}\text { Beta }[95 \% \mathrm{Cl}] \\
\mathbf{k g} / \mathrm{m}^{2} \\
\text { (additive) }\end{array}$ & $\begin{array}{c}\text { Beta }[95 \% \mathrm{Cl}] \\
\text { (knockouts } \\
\text { only) }\end{array}$ \\
\hline $5: 146515831$ & $\mathrm{G}$ & A & Arg95Ter & 53 & 1 & 0.82 & $\begin{array}{c}-0.126 \\
{[-1.23-0.98]}\end{array}$ & \\
\hline $5: 146515817$ & G & T & Tyr99Ter & 945 & 34 & 0.92 & $\begin{array}{c}0.0131 \\
{[-0.24-0.27]}\end{array}$ & $\begin{array}{c}-0.021 \\
{[-1.37-1.33]}\end{array}$ \\
\hline $5: 146515587$ & CTA & C & Phe175LeufsTer7 & 92 & 3 & 0.28 & $\begin{array}{c}0.406 \\
{[-0.32-1.14]}\end{array}$ & \\
\hline Gene Burden & & & & 1,141 & 38 & 0.73 & $\begin{array}{c}0.0405 \\
{[-0.20-0.28]}\end{array}$ & $\begin{array}{c}0.431 \\
{[-0.99-1.85]}\end{array}$ \\
\hline
\end{tabular}

chr, chromosome; pos, position; HGVSp, Human Genome Variation Society protein level change; kg, kilograms; $m$, meter; Cl,

confidence interval

Table 2. Association with T2D

\begin{tabular}{|c|c|c|c|c|c|c|c|c|}
\hline $\begin{array}{l}\text { GRCh38 } \\
\text { chr:pos }\end{array}$ & $\begin{array}{l}\text { Reference } \\
\text { allele }\end{array}$ & $\begin{array}{l}\text { Alternate } \\
\text { allele }\end{array}$ & HGVSp & Cases & Controls & $\mathbf{P}$ & OR $[95 \% \mathrm{Cl}]$ & $\begin{array}{c}\text { OR [95\% Cl] } \\
\text { (knockouts } \\
\text { only) }\end{array}$ \\
\hline $5: 146515831$ & G & A & Arg95Ter & $\begin{array}{l}\text { Hets: } 30 \\
\text { Homs: } 0\end{array}$ & $\begin{array}{l}\text { Hets:54 } \\
\text { Homs:2 }\end{array}$ & 0.24 & $\begin{array}{c}1.85 \\
{[0.67-5.09]}\end{array}$ & \\
\hline $5: 146515817$ & G & $\mathrm{T}$ & Tyr99Ter & $\begin{array}{l}\text { Hets: } 265 \\
\text { Homs: } 1\end{array}$ & $\begin{array}{c}\text { Hets:1115 } \\
\text { Homs:39 }\end{array}$ & 0.08 & $\begin{array}{c}1.15 \\
{[0.98-1.35]}\end{array}$ & $\begin{array}{c}0.99 \\
{[0.34-2.87]}\end{array}$ \\
\hline $5: 146515587$ & CTA & C & Phe175LeufsTer7 & $\begin{array}{l}\text { Hets:29 } \\
\text { Homs:0 }\end{array}$ & $\begin{array}{l}\text { Hets:153 } \\
\text { Homs: } 6\end{array}$ & 0.87 & $\begin{array}{c}1.03 \\
{[0.68-1.59]}\end{array}$ & \\
\hline Gene Burden & & & & $\begin{array}{l}\text { Hets: } 326 \\
\text { Homs: } 1\end{array}$ & $\begin{array}{c}\text { Hets:1358 } \\
\text { Hom: } 47\end{array}$ & 0.03 & $\begin{array}{c}1.18 \\
{[1.02-1.37]}\end{array}$ & $\begin{array}{c}1.60 \\
{[0.42-6.0]}\end{array}$ \\
\hline
\end{tabular}

chr, chromosome; pos, position; HGVSp, Human Genome Variation Society protein level change; OR, odds ratio, Cl, confidence interval, Hets, heterozygotes; Homs, homozygotes 


\section{Supplementary Tables}

Table S1. List of all plof variants with homozygous carriers identified in 30,833 exomes and 9,292 genomes

\begin{tabular}{|c|c|c|c|c|c|c|c|c|}
\hline $\begin{array}{c}\text { GRCh38 } \\
\text { chr:pos }\end{array}$ & $\begin{array}{c}\text { Reference } \\
\text { allele }\end{array}$ & $\begin{array}{c}\text { Alternate } \\
\text { allele }\end{array}$ & $\begin{array}{c}\text { Allele } \\
\text { frequency }\end{array}$ & $\begin{array}{c}\text { Heterozygous } \\
\text { carriers }\end{array}$ & $\begin{array}{c}\text { Homozygous } \\
\text { carriers }\end{array}$ & $\begin{array}{c}\text { Variant } \\
\text { effect }\end{array}$ & HGVSc & HGVSp \\
\hline $5: 146515831$ & G & A & $1.11 \mathrm{E}-03$ & 85 & 2 & stop gained & c.283C>T & p.Arg95Ter \\
\hline $5: 146515817$ & G & T & $1.84 \mathrm{E}-02$ & 1394 & 40 & stop gained & c.297C>A & p.Tyr99Ter \\
\hline $5: 146515587$ & CTA & C & $2.44 \mathrm{E}-03$ & 184 & 6 & frameshift & c.525_526del & p.Phe175LeufsTer7 \\
\hline
\end{tabular}

chr, chromosome; pos, position; HGVSc and HGVSp, Human Genome Variation Society coding or protein level change,

respectively

\section{Table S2. Association with waist-to-hip ratio and lipid related biomarkers}

\begin{tabular}{|c|c|c|c|c|c|c|c|c|}
\hline $\begin{array}{l}\text { GRCh38 } \\
\text { chr:pos }\end{array}$ & $\begin{array}{l}\text { Reference } \\
\text { allele }\end{array}$ & $\begin{array}{l}\text { Alternate } \\
\text { allele }\end{array}$ & Phenotype & HGVSp & $\begin{array}{l}\text { Heterozygous } \\
\text { carriers }\end{array}$ & $\begin{array}{c}\text { Homozygous } \\
\text { carriers }\end{array}$ & $\mathbf{P}$ & $\begin{array}{c}\text { Beta [95\% Cl] } \\
\text { (additive) }\end{array}$ \\
\hline $\begin{array}{c}\text { plof Gene } \\
\text { Burden }\end{array}$ & & & \multirow{4}{*}{$\begin{array}{l}\text { Cholesterol } \\
(\mathrm{mg} / \mathrm{dl})\end{array}$} & & 1599 & 45 & 0.242 & $\begin{array}{c}1.414 \\
{[-0.957-3.786]}\end{array}$ \\
\hline $5: 146515831$ & G & A & & Arg95Ter & 78 & 2 & 0.740 & $\begin{array}{c}1.790 \\
{[-8.777-12.357]}\end{array}$ \\
\hline $5: 146515817$ & G & $\mathrm{T}$ & & Tyr99Ter & 1316 & 38 & 0.598 & $\begin{array}{c}0.700 \\
{[-1.9-3.3]}\end{array}$ \\
\hline $5: 146515587$ & CTA & C & & Phe175LeufsTer7 & 171 & 5 & 0.383 & $\begin{array}{c}3.161 \\
{[-3.94-10.26]}\end{array}$ \\
\hline $\begin{array}{c}\text { plof Gene } \\
\text { Burden }\end{array}$ & & & \multirow{4}{*}{$\begin{array}{l}\text { Triglycerides } \\
(\mathrm{mg} / \mathrm{dl})\end{array}$} & & 1591 & 45 & 0.925 & $\begin{array}{c}0.274 \\
{[-5.384-5.93]}\end{array}$ \\
\hline $5: 146515831$ & G & A & & Arg95Ter & 79 & 2 & 0.581 & $\begin{array}{c}7.060 \\
{[-18.014-} \\
32.133] \\
\end{array}$ \\
\hline $5: 146515817$ & G & $\mathrm{T}$ & & Tyr99Ter & 1307 & 38 & 0.855 & $\begin{array}{c}-0.580 \\
{[-6.784-5.623]}\end{array}$ \\
\hline $5: 146515587$ & CTA & C & & Phe175LeufsTer7 & 171 & 5 & 0.862 & $\begin{array}{c}-1.507 \\
{[-18.44-15.42]}\end{array}$ \\
\hline $\begin{array}{c}\text { plof Gene } \\
\text { Burden }\end{array}$ & & & \multirow{4}{*}{$\begin{array}{l}\text { Waist Hip } \\
\text { Ratio }\end{array}$} & & 1263 & 42 & 0.567 & $\begin{array}{c}-0.001 \\
{[-0.004-0002]}\end{array}$ \\
\hline $5: 146515831$ & G & A & & Arg95Ter & 56 & 2 & 0.147 & $\begin{array}{c}0.010 \\
{[-0.004-0.024]}\end{array}$ \\
\hline $5: 146515817$ & $\mathrm{G}$ & $\mathrm{T}$ & & Tyr99Ter & 1035 & 37 & 0.222 & $\begin{array}{c}-0.002 \\
{[-0.005-0.001]}\end{array}$ \\
\hline $5: 146515587$ & CTA & C & & Phe175LeufsTer7 & 144 & 3 & 0.844 & $\begin{array}{c}-0.001 \\
{[-0.010-0.008]}\end{array}$ \\
\hline
\end{tabular}

chr, chromosome; pos, position; HGVSp, Human Genome Variation Society protein level change; kg, kilograms; $\mathrm{m}$, meter; Cl,

confidence interval; $\mathrm{mg} / \mathrm{dl}$, milligrams per deciliter

Table S3. Association with MI

\begin{tabular}{|c|c|c|c|c|c|c|c|c|}
\hline $\begin{array}{l}\text { GRCh38 } \\
\text { chr:pos }\end{array}$ & $\begin{array}{l}\text { Reference } \\
\text { allele }\end{array}$ & $\begin{array}{l}\text { Alternate } \\
\text { allele }\end{array}$ & HGVSp & Cases & Controls & $\mathbf{P}$ & OR $[95 \% \mathrm{Cl}]$ & $\begin{array}{c}\text { OR [95\% Cl] } \\
\text { (knockouts } \\
\text { only) }\end{array}$ \\
\hline $5: 146515831$ & G & A & Arg95Ter & $\begin{array}{l}\text { Hets: } 50 \\
\text { Homs: } 2\end{array}$ & $\begin{array}{l}\text { Hets:35 } \\
\text { Homs:0 }\end{array}$ & 0.33 & $\begin{array}{c}1.39 \\
{[0.71-2.72]}\end{array}$ & \\
\hline 5:146515817 & G & $\mathrm{T}$ & Tyr99Ter & $\begin{array}{l}\text { Hets: } 736 \\
\text { Homs: } 14\end{array}$ & $\begin{array}{l}\text { Hets: } 658 \\
\text { Homs:26 }\end{array}$ & 0.90 & $\begin{array}{c}0.99 \\
{[0.89-1.10]}\end{array}$ & $\begin{array}{c}0.81 \\
{[0.38-1.71]}\end{array}$ \\
\hline $5: 146515587$ & CTA & C & Phe175LeufsTer7 & $\begin{array}{l}\text { Hets:100 } \\
\text { Homs:0 }\end{array}$ & $\begin{array}{l}\text { Hets:84 } \\
\text { Homs:2 }\end{array}$ & 0.44 & $\begin{array}{c}0.90 \\
{[0.68-1.18]}\end{array}$ & \\
\hline Gene Burden & & & & $\begin{array}{l}\text { Hets: } 913 \\
\text { Homs:20 }\end{array}$ & $\begin{array}{l}\text { Hets:789 } \\
\text { Hom:28 }\end{array}$ & 0.5 & $\begin{array}{c}1.04 \\
{[0.39-2.76]}\end{array}$ & $\begin{array}{c}1.11 \\
{[0.5-2.4]}\end{array}$ \\
\hline
\end{tabular}

chr, chromosome; pos, position; HGVSp, Human Genome Variation Society protein level change; OR, odds ratio, Cl, confidence interval 
medRxiv preprint doi: https://doi.org/10.1101/2021.10.21.21264378; this version posted October 26, 2021. The copyright holder for this preprint

(which was not certified by peer review) is the author/funder, who has granted medRxiv a license to display the preprint in perpetuity.

It is made available under a CC-BY-NC-ND 4.0 International license.

\section{Figure captions}

Figure 1. GPR151 variant proteins are not stably expressed. Western blot expression of HEK293 cells transfected with pcDNA3.1 plasmids encoding GPR151 variants with $\mathrm{N}$-terminal $\mathrm{HA}$-tag. $\mathrm{Na}^{+} / \mathrm{K}^{+}$ATPase is shown as a loading control.

Figure 2. Male Gpr $151^{-/}$mice gain weight on high fat diet. (A and C) Sections of mouse brain containing the medial habenula $(\mathrm{MHb})$ and lateral habenula $(\mathrm{LHb})$ from wild type and $\mathrm{Gpr} 151^{-/}$mice, respectively, stained with a riboprobe for Gpr151. (B and D) Sections of mouse intestine containing the ileum and jejunum from wild type and Gpr151/- mice, respectively, stained with a riboprobe for Gpr151. Black arrows indicate cells containing Gpr151 mRNA. (E) Body weights of male wild type and Gpr151/- mice on a standard chow diet and high fat diet. Data are presented as \pm standard error of the mean (SEM). * $p<$ 0.05 , repeated measures, two-way ANOVA followed by post-hoc analysis using Sidak's multiple comparisons test. (F) Cumulative food intake male wild type and Gpr $151^{-\%}$ mice on a standard chow diet and high fat diet. Data are presented as \pm SEM. (G) Body weights of female wild type and Gpr $151^{-/}$mice on a standard chow diet and high fat diet. Data are presented as \pm SEM. 


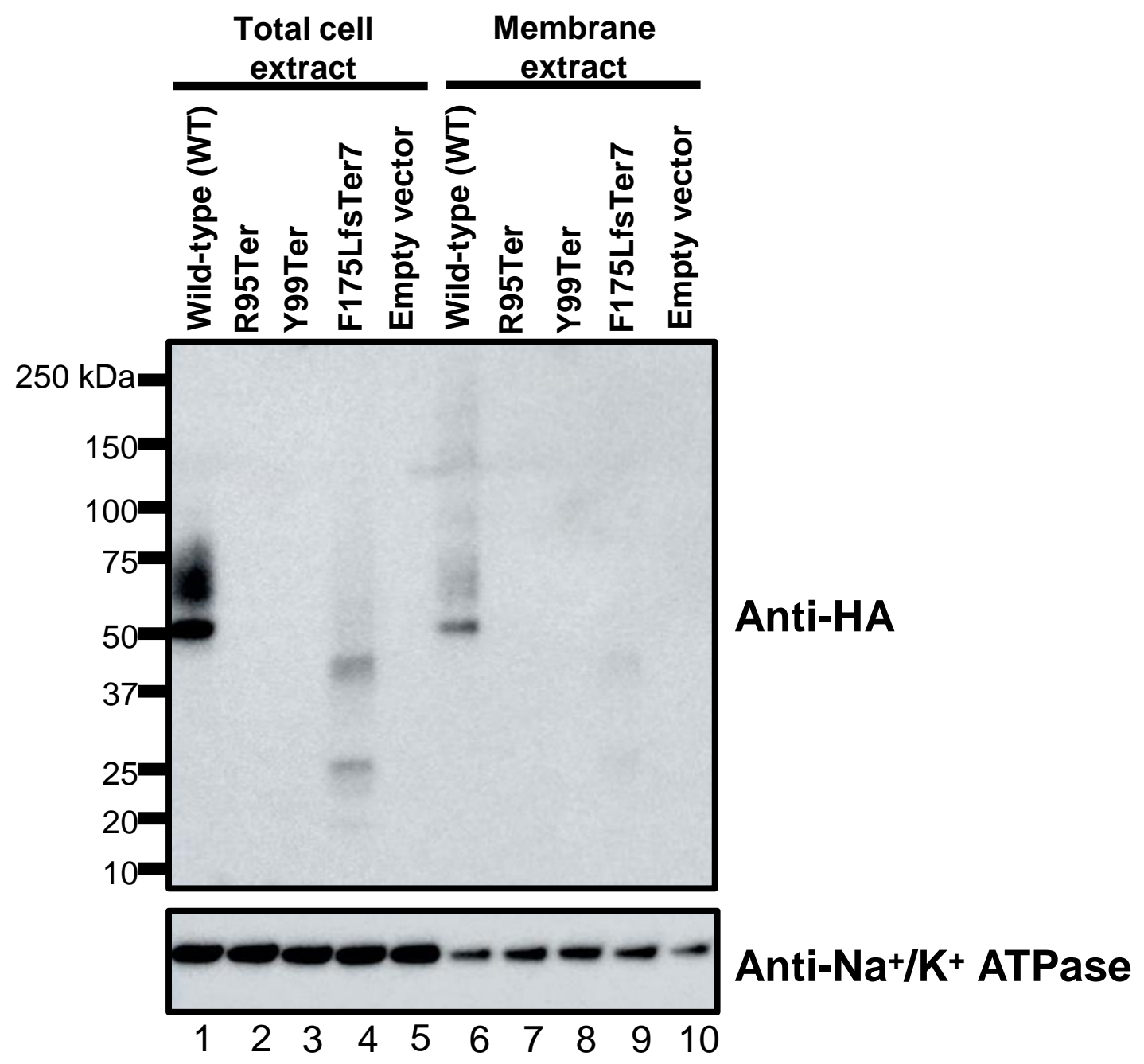

Figure 1. GPR151 variant proteins are not stably expressed. Western blot expression of HEK293 cells transfected with pcDNA3.1 plasmids encoding GPR151 variants with $\mathrm{N}$-terminal $\mathrm{HA}$-tag. $\mathrm{Na}^{+} / \mathrm{K}^{+}$ ATPase is shown as a loading control. 


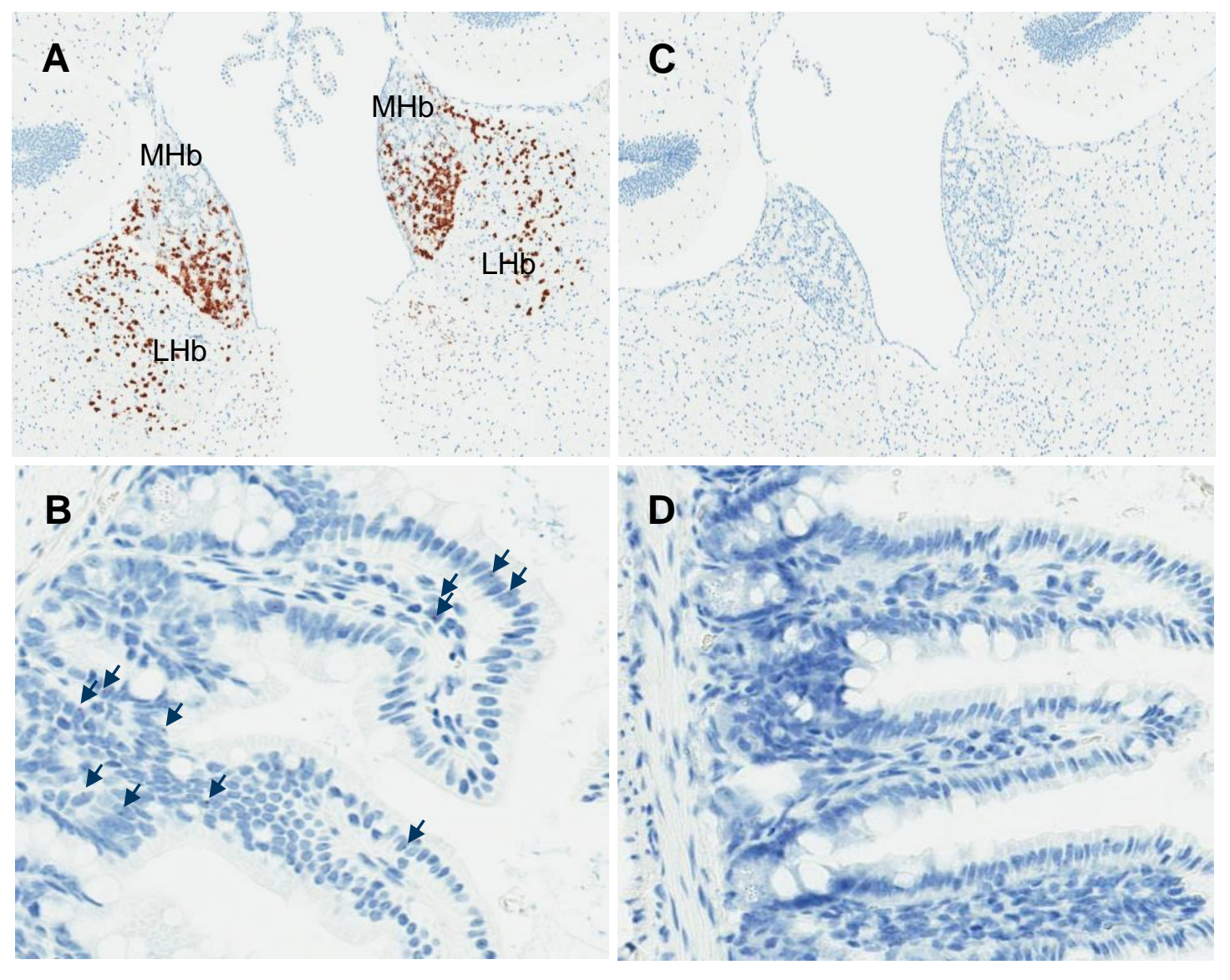

Figure 2. Male Gpr151\%- mice gain weight on high fat diet.

(A and C) Sections of mouse brain containing the medial habenula $(\mathrm{MHb})$ and lateral habenula $(\mathrm{LHb})$ from wild type and Gpr151/- mice, respectively, stained with a riboprobe for Gpr151.

(B and D) Sections of mouse intestine containing the ileum and jejunum from wild type and Gpr151- mice, respectively, stained with a riboprobe for Gpr151. Black arrows indicate cells containing Gpr151 mRNA. 
E

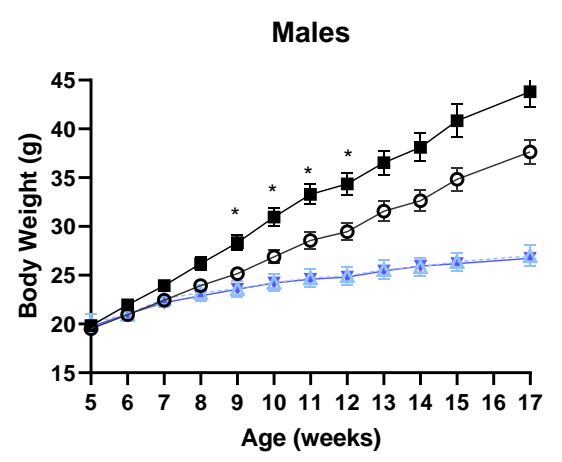

G

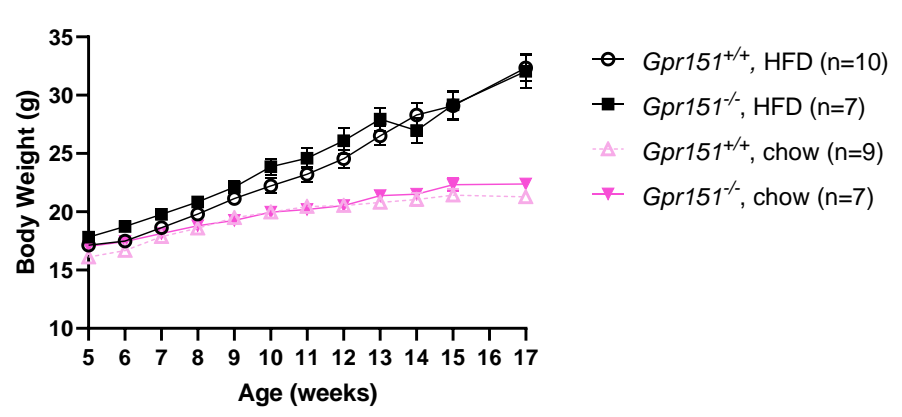

Figure 2 (continued)

(E) Body weights of male wild type and Gpr151\% mice on a standard chow diet and high fat diet. Data are presented as \pm standard error of the mean (SEM). * $p<0.05$, repeated measures, two-way ANOVA followed by post-hoc analysis using Sidak's multiple comparisons test.

(F) Cumulative food intake male wild type and Gpr151\% mice on a standard chow diet and high fat diet. Data are presented as \pm SEM.

(G) Body weights of female wild type and Gpr151- mice on a standard chow diet and high fat diet. Data are presented as \pm SEM. 